\title{
MYH1 wt Allele
}

National Cancer Institute

\section{Source}

National Cancer Institute. MYH1 wt Allele. NCI Thesaurus. Code C112131.

Human MYH1 wild-type allele is located in the vicinity of $17 \mathrm{p} 13.1$ and is approximately 26 $\mathrm{kb}$ in length. This allele, which encodes myosin-1 protein, is involved in the contraction of skeletal muscles. 